\title{
Trade credit and bank loan in period of financial crisis: Evidence from Tunisian exporting companies
}

\author{
Meryem Bellouma*
}

Lecturer in Faculty of Economics and Management of Nabeul, Tunisia

\begin{tabular}{|c|c|}
\hline CHRON I C LE & A B S T R A C T \\
\hline $\begin{array}{l}\text { Article history: } \\
\text { Received December } 5,2015 \\
\text { Received in revised format } \\
\text { February } 162016 \\
\text { Accepted August } 82016 \\
\text { Available online } \\
\text { August } 82016 \\
\text { Keywords: }\end{array}$ & $\begin{array}{l}\text { This paper examines the relationship between trade credit and bank loan during the financial } \\
\text { crisis using annual data on Tunisian exporting companies over the period 2005-2011. Results } \\
\text { based on 2SLS regression have shown that trade credit and bank credit were simultaneously } \\
\text { determined and maintained a complementary effect before } 2008 \text { financial crisis. On the other } \\
\text { side, the substitution effect has been detected between the two sources of short term financing } \\
\text { during } 2008 \text { financial crisis. Finally, companies rely more on bank loan after the financial crisis } \\
\text { because bankers are able to cover financial need of their customers. }\end{array}$ \\
\hline
\end{tabular}

Trade credit

Financial constraints

Tunisian exporting companies

\section{Introduction}

The credit crunch of 2008 resulted in contraction in bank financing and in the reluctance of financial institutions to supply loans for companies. The cash constraints can lead to serious cash flow problems. Academic studies have stressed the importance role of credit on company growth and performance (Bellouma, 2015). Therefore, the reduction of credit offered by financial institutions can harm the company's sales. To overcome this situation, companies may rely on trade credit. In fact, suppliers can provide to their customers additional credit or delay the repayment period. In the early 60's Meltzer (1960) presented the trade credit as a substitute for the loan bank. He has exposed the redistribution function of non-financial firms. In times of financial distress, liquid companies extend paying terms of their customers. Thus, they redistribute their funds towards the less creditworthy companies to consolidate their sales. Another strand of the literature supports the complementary perspective between trade credit and bank credit. Burkart and Ellingsen (2004) argue that bank credit is a long term source of financing, while trade credit is used in a short term horizon. Since companies need both short term and long term credit, the two types of credit are complementary. The financial crisis clearly results in reducing the bank credit availability for companies. Rationed companies are likely to search others options to finance their working capital (Biais \& Gollier, 1997). Hence, the trade

\footnotetext{
* Corresponding author

E-mail address: mbellouma@yahoo.fr (M. Bellouma) 
credit is one of their financing sources. From the view of substitutable role of trade credit, this research focuses on the effects of the financial crisis on the availability of trade credit. Although the offer of trade credit and the offer of bank loan are independent, the question whether they have causal relationship is still unclear. Several empirical studies have been conducted to detect whether trade credit and bank credit are substitutable or complementary in many developing or emerging countries (Taketa \& Udell, 2007; Jain, 2001, Demirgüç-Kunt \& Maksimovic, 2001 ...). However, this study is the first research who aims to understand this link on the basis of Tunisian exporting SMEs since trade credit decision is crucial for them. This subject is very relevant nowadays because of the necessity to understand if trade credit presents a tool to soften the impact of the financial crisis.

Besides, previous studies have ignored the problem of endogeneity between trade credit and bank credit and stressed the substitute effect (Nilsen, 2002). However, there is none investigation on the reverse causation relationship. More precisely, we attempt in this paper to verify if the information gathered by suppliers about their customers is used by bank to offer credit to these borrowers with recognized creditworthiness. The paper is organized as follows. Section two briefly provides the literature review and presents the hypotheses. Section three describes the methodology adopted. Section four exposes the findings. Finally, section five concerns the conclusion.

\section{Literature review}

As noted by Petersen and Rajan (1997), the use of trade credit is explained by three theories. According to the financial theory, suppliers have an advantage over financial institution in monitoring and collecting information about their customers in the presence of information friction (Schwartz, 1974). The second theory that explains the use of trade credit is price discrimination theory. A supplier with incentive to make additional sales, uses trade credit to discriminate between its customers. A bankrationed customer will use trade credit to finance its working capital. However, a creditworthy company seeks early payment in order to beneficiate of discount because trade credit is expensive. The third theory is transaction costs theory. Trade credit implies two transactions cost advantages (Ferris, 1981).

On one hand, the company holds less cash balances. On the other hand, in periods of low demand, trade credit may stimulate sales and reduces managing costs of inventory. Another explanation addressed by Smith (1987) is the implicit guarantee offered by trade credit. In fact, the period of the trade credit is used as time for the customers to evaluate the quality of the delivered goods. As one can note, these theories are directly linked to the use of the trade credit. Specially, the static arguments given by transaction costs and implicit guarantee cannot explain trade credit during financial contraction. However, the financial advantage theory and the price discrimination theory are used to explain trade credit granted to less creditworthy companies with financial difficulties. Consequently, according to the redistribution view of Meltzer (1960), creditworthy companies who accede to bank credit offer more trade credit (Burkart \& Ellingsen, 2005; Love et al., 2007).

Basically, the financial assistance view combined with the price discrimination price is developed during financial distress when liquid suppliers use their accumulated funds in increasing the average length of their receivables because of generating further sales at a higher price. In addition, non-rationed suppliers redistribute implicitly the bank credit that they get to the relatively less creditworthy companies. Thus, bank rationed companies can finance their businesses by using trade credit as long as the supplier may extend extra trade credit (Yang, 2011). The arguments given shows the link between the redistribution view and price discrimination. As mentioned earlier, the second explanation for using trade credit in period of crisis is the financial advantage. Contrary to financial institutions, suppliers can threaten their customers to cut off future deliveries or to resell customer's inventory in case of financial distress. From the empirical view, many researches have explored the relationship between bank loan and trade credit. Taketa and Udell (2007) find trade credit as a substitute of other bank lending during financial crisis in Japan. However, Burkart and Ellingsen (2004) Demirgüc, and Maksimovic (2001) note that trade credit and bank credit are complementary. By introducing, 
monitoring cost, Jain (2001) find that supplier can play the same role of financial intermediary and trade can serve as a cushion in a period of crisis.

\section{Data and empirical results}

We have collected data of exporting companies from Tunisian Export Promotion Center (CEPEX). The choice of Export companies is explained by the importance of trade credit for them and the influence of the global financial crisis on their transaction. Data have been extracted from Financial Statement of 300 exporting Tunisian companies. To test the impact of 2008 financial crisis we have used the data from 2005 to 2011 . We have then divided this interval into 3 main parts as pre financial crisis (20052007), during financial crisis (2008) and postfinancial crisis (2009-2011). Specifically, 115 companies work at the food industry, 84 product construction materials, 71 run textile business, 14 operate in metal industry and 16 have a service activity. The panel is mainly composed of limited liability companies (69.3\%). The limited corporations represent only $21.2 \% .23 .4 \%$ of companies in the sample export over $50 \%$ of their products towards four foreign markets (U.S, Asia, Europe and Arabic Maghreb union). $58.7 \%$ employ less than 50 workers. Thus, they are considered as small and medium-sized companies.

We report in Table 1 descriptive statistics for the sample used in this study. To focus on the simultaneous feature of trade credit and bank credit we have selected these dependent variables (Cunat, 2007; Vaidya, 2011; Yang, 2011; Niskanen \& Niskanen, 2006; Bellouma, 2015):

$\Delta$ trade credit $(\Delta \mathrm{TC})$ : is the difference between account receivables and account payables to total assets. This variable indicates whether the company gives or receives trade credit.

Short-term bank credit (STBC): is calculated as short-term debt divided by total assets.

Control variables: Size (SIZE: measured by number of employee), inventory (INV: is measured by the ratio of inventory to total assets), sales growth (SGROW: is the amount of sales increased in current year as compare to last year) and cash (CASH: is the amount of cash divided by total assets).

Table 1

Descriptive statistics

\begin{tabular}{llllll}
\hline & Mean & Medium & Standard deviation & Minimum & Maximum \\
\hline$\Delta$ TC & $-0,023$ & 0,022 & 0,256 & $-0,975$ & 0,586 \\
STBC & 10,438 & 2,367 & 22,487 & 0,015 & 137,4 \\
SIZE & 7,845 & 7,635 & 1,603 & 2,344 & 13,01 \\
SGROW & 0,109 & 0,154 & 0,402 & $-1,460$ & 3,807 \\
INV & 0,174 & 0,116 & 0,134 & 0,000 & 0,680 \\
CASH & 0,052 & 0,013 & 0,059 & 0,000 & 0,789 \\
\hline
\end{tabular}

Contrary to the previous empirical investigations, this study attempts to verify the endogeneity between trade credit and bank credit. Thus, we could not apply Ordinary Least Square (OLS) or weighted least square (WLS), because of the presence of correlation between explanatory variables and error term. To produce consistent and unbiased estimators, we have used instrumental variable regression. Therefore, 2SLS analysis technique has been retained to estimate these simultaneous equations.

$$
\begin{aligned}
& \Delta \text { TC }_{i t}=\alpha_{0}+\alpha_{1} \text { STBC }_{t}+\alpha_{2 y} \text { Bfcrisis }_{y t}+\alpha_{3} \text { Crisist }+\alpha_{4 y} \text { AfCrisis }_{y t}+\alpha_{5} \text { CONTROL }_{i t}+\mu_{i}+ \\
& \mathcal{E}_{i t} \\
& \triangle \text { STBC }_{i t}=\beta_{0}+\beta_{1} \Delta T C_{t}+\beta_{2 y} \text { Bfcrisis }_{y t}+\beta_{3} \text { Crisis }_{t}+\beta_{4 y} \text { AfCrisis }_{y t}+\beta_{5} \text { CONTROL }_{i t}+\mu_{i}+\varepsilon_{i t}
\end{aligned}
$$

where, Bfcrisis yt are dummy variables for the year before the financial crisis $(y=2006$ or 2007). Crisist is a dummy variable for the year 2008. AfCrisis $y$ are dummy variables for the year after crisis ( $\mathrm{y}=$ 2009 or 2010 or 2011). Bfcrisis 2005t is a dummy variable for the year 2005 that is used as a benchmark. CONTROL $_{\text {it }}$ are vectors of the control variables (size, inventory, liquidity, sales growth, fixed assets and cash). $\mu_{\mathrm{i}}$ is firm specific effects. $\varepsilon_{\mathrm{it}}$ is the error term. 
Table 2

2SLS Estimation

\begin{tabular}{|c|c|c|}
\hline & Column A: Equation 1 & Column B: Equation 2 \\
\hline Constant & $\begin{array}{l}0.234^{* *} \\
(0.116)\end{array}$ & $\begin{array}{l}-73.85^{* * *} \\
(6.331)\end{array}$ \\
\hline$\Delta \mathrm{TC}$ & & $\begin{array}{l}-12.732^{* * *} \\
(2.087)\end{array}$ \\
\hline STBC & $\begin{array}{l}0.004^{* * *} \\
(0.0005)\end{array}$ & \\
\hline Bfcrisis 2006 & $\begin{array}{l}-0.103^{* *} \\
(0.005)\end{array}$ & $\begin{array}{l}0.080^{* * *} \\
(0.021)\end{array}$ \\
\hline Bfcrisis $_{2007}$ & $\begin{array}{l}-0.326^{* *} \\
(0.056)\end{array}$ & $\begin{array}{l}0.809 \\
(0.714)\end{array}$ \\
\hline Crisis & $\begin{array}{l}0.035^{* *} \\
(0.016)\end{array}$ & $\begin{array}{l}-1.084^{* * *} \\
(0.004)\end{array}$ \\
\hline Afcrisis $_{2009}$ & $\begin{array}{l}0.030^{* * *} \\
(0.006)\end{array}$ & $\begin{array}{l}-1.789^{*} \\
(1.134)\end{array}$ \\
\hline Afcrisis $_{2010}$ & $\begin{array}{l}0.056^{* * *} \\
(0.015)\end{array}$ & $\begin{array}{l}-1.906 \\
(1.204)\end{array}$ \\
\hline Afcrisis $_{2011}$ & $\begin{array}{l}0.109^{* * *} \\
(0.018)\end{array}$ & $\begin{array}{l}0.001^{* * *} \\
(0.024)\end{array}$ \\
\hline \multicolumn{3}{|l|}{ CONTROL } \\
\hline SIZE & $\begin{array}{l}-0.016 \\
(0.014)\end{array}$ & $\begin{array}{l}11.908^{* * *} \\
(0.799)\end{array}$ \\
\hline \multicolumn{3}{|l|}{ SGROW } \\
\hline INV & $\begin{array}{l}-0.234^{* * *} \\
(0.054)\end{array}$ & $\begin{array}{l}-14.281^{* * *} \\
(4.113)\end{array}$ \\
\hline CASH & $\begin{array}{l}-0.862^{* * *} \\
(0.054)\end{array}$ & $\begin{array}{l}-11.329^{* * *} \\
(4.921)\end{array}$ \\
\hline Adjusted $\mathrm{R}^{2}$ & 0.601 & 0.782 \\
\hline
\end{tabular}

As mentioned in Table 2 in column A, bank credit has a positive and significant impact on net trade credit. It means that the availability of bank credit encourage suppliers to grant trade credit to their customers and then increase their receivables. This result implies the complementary role of bank credit. The significant and negative coefficient of net trade credit shown in column B highlighted the substitutable effect. Indeed, the increase in bank credit tend to decrease the amount of net trade credit. When customers are bank rationed it is quite possible that they will finance their short term transaction by negotiating trade credit with their suppliers. The dummy variable of pre financial crisis has significant and positive impact on bank credit. We have noted that net trade credit decreased before financial crisis. Thus, because of the availability of bank credit, Tunisian exporting companies rely less on trade credit. However, positive and significant results for financial crisis dummies variables during crisis and post crisis have indicated that companies were searching financing from their suppliers. More explicitly, companies were not able to carry out credit transactions with their bank, so they switch to their suppliers. These results implied the substitution effect between trade credit and bank credit. In 2011, after two years from the financial crisis banks were able to finance their customers as reported in column B. This behavior could be explained as a first short term reaction immediately after the financial crisis.

For the control variables, Size, inventory and cash have significant impact on bank credit. Expect size, all the other control variables have significant effect on net trade credit. Probably the strong negative effect of cash and inventory on trade credit can be explained by the substitute effect. In fact, more company's working capital was located on cash or inventory the less working capital was available to finance the need of the customer. 


\section{Conclusion}

Trade credit is an important source for financing short-term need of companies. The main objective of this research was to see whether trade credit captivates the negative impacts of the financial crisis on the capacity of bankers to grant credit. Thus, this study has tested the causal relationship between trade credit and bank credit. Annual data have been collected from Tunisian exporting companies. We have found that bank credit have a positive and significant impact on net trade credit which indicate the complementary effect between the two sources of financing. The substitute effect between trade credit and bank credit has been detected. To distinguish the influence of financial crisis, we divided the sample into three main classes of before, during and after financial crisis. The most important results is that companies relied more on trade credit during financial crisis. Furthermore, short term bank credit is used by creditworthy companies to accomplish redistribution role.

Future investigation on this subject should include statements of defaulted companies to make a comparison between defaulted and creditworthy firms.

The ability to explain the use of trade credit based only on data from financial statements is limited. Therefore, future study should take into account additional information like the relationship between the customer and the supplier.

\section{References}

Bellouma, M. (2015). The determinants of trade Credit: Evidence from Tunisian export SMEs. EuroAsian Journal of Economics and Finance, 3(1), 64-72.

Biais, B., \& Gollier, C. (1997). Trade credit and credit rationing. Review of financial studies, 10(4), 903-937.

Blasio, G. D. (2005). Does trade credit substitute bank credit? Evidence from firm-level data. Economic notes, 34(1), 85-112.

Burkart, M., \& Ellingsen, T. (2004). In-kind finance: A theory of trade credit.The American economic review, 94(3), 569-590.

Cunat, V. (2007). Trade credit: suppliers as debt collectors and insurance providers. Review of Financial Studies, 20(2), 491-527.

Demirgüç-Kunt, A., \& Maksimovic, V. (2001). Firms as financial intermediaries: Evidence from trade credit data (Vol. 2696). World Bank, Development Research Group, Finance.

Ferris, J. S. (1981). A transactions theory of trade credit use. The Quarterly Journal of Economics, 96(2), 243-270.

Jain, N. (2001). Monitoring costs and trade credit. The Quarterly Review of Economics and Finance, 41(1), 89-110.

Love, I., Preve, L. A., \& Sarria-Allende, V. (2007). Trade credit and bank credit: Evidence from recent financial crises. Journal of Financial Economics, 83(2), 453-469.

Meltzer, A. H. (1960). Mercantile credit, monetary policy, and size of firms.The Review of Economics and Statistics, 42(4), 429-437.

Nilsen, J. H. (1999). Trade credit and the bank lending channel. Journal of Money, Credit and Banking, 34(1), 226-253.

Niskanen, J., \& Niskanen, M. (2006). The Determinants of Corporate Trade Credit Policies in a Bankdominated Financial Environment: the Case of Finnish Small Firms. European Financial Management, 12(1), 81-102.

Petersen, M., \& Rajan, R. (1997). Trade credit: Theories and evidence. Review of Financial Studies, 10, 661-691.

Schwartz, R. A. (1974). An economic model of trade credit. Journal of financial and quantitative analysis, 9(04), 643-657.

Smith, J. (1987). Trade credit and information asymmetry. Journal of Finance, 4, 863-869. 
Taketa, K., \& Udell, G. F. (2007). Lending channels and financial shocks: The case of small and medium-sized enterprise trade credit and the Japanese banking crisis. Monetary and Economic Studies, 25(2), 1-44.

Vaidya, R. R. (2011). The determinants of trade credit: Evidence from Indian manufacturing firms. Modern Economy, 2(05), 707.

Yang, X. (2011). The role of trade credit in the recent subprime financial crisis. Journal of Economics and Business, 63(5), 517-529. 